\title{
STUDY THE CHARACTERISTICS OF PUBLIC BUS ROUTES IN AL KUT CITY
}

\author{
"Shaymaa F. Balket'
}

Noor M. Asmael ${ }^{1}$

1) Highway and Transportation Engineering Department, College of Engineering, Mustansiriyah University, Baghdad, Iraq

\begin{abstract}
This paper focused on studying the service characteristics of bus routes in the city of Kut, such as determining the stopping points for each of the public transport lines in the study area, the total boarding and disembarkation of passengers at each station, determining the location of the bus route, time, distance traveled and the number of passengers in the bus, estimating the demand of passengers on the bus route. This study aims to assess the efficiency of the performance of the public transport network and help decision makers to identify the problem of traffic congestion in the streets of the city for take the necessary measures to make improvements to the public transport network and thus encourage citizens to use them, which contributes to alleviating the traffic of congestion in the streets of the city, as the number of bus service lines in the city of Kut was 12 routes throughout the city. Two types of field surveys were conducted on these routes for the purpose of data collection, namely the ride check survey, and the point check survey. The results of the analysis in this study, which depended on collecting data and determining where and how passengers used the service, showed that the paths (Al-Sawadah, Al-Khajia, AlAnwar, Al-Hawra) have the greatest demand for travel with a value of $(2880,2810,2560,2392)$ passenger/hour respectively. Also the boarding and alighting of passengers is not high in most of the roads and that some roads are of low load.
\end{abstract}

Keywords: Public Bus Routes, Ride Check Survey, Point Check Survey, Kut City.

\section{Research objectives}

The purpose of preparing the research is:
- Determining the stopping points for each public transport route in the study area and the total boarding and alighting of passengers at each stop.

- Determine bus route location, time, distance traveled and number of passengers on the bus.

- Estimated passenger demand on the bus route.

- The research is a starting point for decision makers to find out the causes of the traffic momentum problem in the city streets and to make improvements in the performance of public transportation mean to encourage citizens to use it.

\section{The Statement of Problem}

Public transportation in the city of Kut faces great challenges through the lack of studies in the field of transport planning and the weakness of the local government in providing adequate conditions for public transport such as wide vehicles, comfortable seats and other environmentally friendly means of transport that are almost non-use in the city of Kut, where the dependence is heavily on vehicles type (Kia) And a medium-sized bus, most of which are old which do not operate in an integrated way and in fact

\footnotetext{
*Corresponding Author: engshaymaa2019@gmail.com
} 
compete with each other for the passengers and reduce the flexibility of movement and their numbers reach 265 vehicles Within the boundaries of Al Kut city.

\section{Introduction}

The urban bus service system is the most important component of public transportation. The quality of bus services is assessed by exploring the spatial configuration of the bus service system and that this assessment is of great importance in urban transportation planning [1].

Running the bus service efficiently and effectively in terms of supply and demand is essential to choose people for this mode more appropriate. Performance can be measured through service use, service accessibility, and service quality [2]. Numerous studies were led to define key performance pointers for public transport services. Anderson and Fielding utilized factor analysis to decrease 48 performance pointers to (7) metrics in an attempt to reduce the number of pointers [3]. Then Benn pointers a number of these inputs and classified them into five groups to define the evaluation criteria, which are path design, monitoring service provision, schedule design, passenger comfort, and safety, economy, and productivity, the study concluded that service quality and operating cost are the two most important factors for evaluating the overall effectiveness of the service for users [4]. To evaluate the performance of bus service for Spanish transport systems, Sanchez utilized several output variables such as vehicle kilometers, hours of service, seat capacity, and the number of passengers [5]. Lao and Liu assessed bus route performance using operating time, number of stops, operational efficiency, and the total number of bus users [6]. In this study (Yetiskul and Senbil, 2012), identified the basic determinant of transportation in travel, which is the travel variable through the data collected in the Turkish capital, Ankara.
Three models have been developed to study the variation in travel time of the public transport system caused by operational areas and highways and the results showed that the reasons for the change in travel time are the spatial dimension, service characteristics and the time dimension [7]. (Beirão and Cabral, 2007) also referred to the attributes that lead to an increase in the use of public transportation, such as the type of trip, individual characteristics, service performance and lifestyle, and that the service must be designed in a way that equates to the service requirements customers [8]. (Zainab et al, 2018) used Transcad program and GIS technologys to assess the transportation network in Nasiriyah city by collecting data such as traffic volumes and free flow velocity using a MSSS device. The results showed that the service level of the network is of type $\mathrm{F}$, and that most roads in the city have a service level of type $B$, as the ratio $\mathrm{V} / \mathrm{C}$ is greater than one in the city center, Such as Al-Haboubi Street, Sumer Street and Nasser Bridge[9].

\section{Study Area}

The study area is the city of Kut, the center of Wasit Governorate, is located between two latitudes $\left(32^{\circ} 21^{\prime}\right.$ and $\left.32^{\circ} 34^{\prime}\right)$ north and longitudes $\left(45^{\circ} 54^{\prime}\right.$ and $\left.45^{\circ} 45^{\prime}\right)$ east, with an average height of about 20 meters. The area of the governorate is 17,153 square kilometers, as for the city of Kut, the built-up area it covers is about 40 square kilometers (4000 hectares), and it is located in an important location on the Tigris River that surrounds the city center on three sides and on close to the north of the city, two branches, branch out from the river (Al-Gharaf and Al-Dujaili) [10] as shown in Figure (1). As for the spatial location and its relationship with the neighboring regions. So the city of Kut is linked to Baghdad, as it is about (180) km away from it, and is distinguished by its middle location between the main cities surrounding it, 
with an average distance of approximately 220 $\mathrm{km}$ from Amara, Nasiriyah to the south, Diwaniyah, and Hellah to the west which this location made it a city with a variety of regional relations. The location city on the road network that connects Baghdad and the southern governorates, especially Basra a port, gave the city a distinctive status in commercial exchange and stimulated commercial movement within it, and also led to the city's growth industrially and commercially.

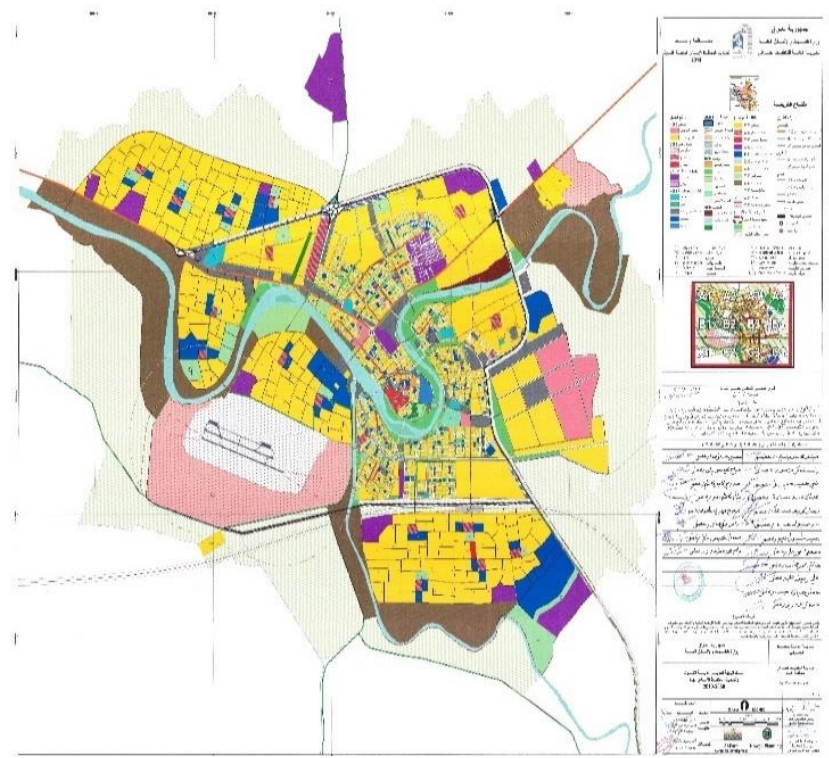

Figure 1. Basic design map of the city of Kut. ( Ref. Municipality directorate - 2014)

Another advantage is added to it, which is the proximity to the most important border points with Iran, that is, the city of Badra, which is located at a distance of $70 \mathrm{~km}$ to the north of the city of Kut, which gave Kut and Wasit governorate a vital and strategic location. Despite this, the majority of traffic activities are still dealt with individual cases in the absence of studies at the general levels of the city and without comprehensive techniques for transportation issues.

\section{Public Bus Routes in Al Kut City}

Public transport in the city of Kut depends on mini buses (Kia) in most public transport lines, with few lines still relying on medium-sized buses (28) passengers. As for the large buses, they are not used on public transport in Al Kut. As for the main garage, it is located in the commercial center and in Hay Al Rabee'a Street, which is bounded by Wasit University.Most of the lines depart to the north of the city, where is the largest part of the city, it takes Al-Naseej Street as a corridor, after that it is distributed from Al-Mutanabbi Square towards Maysan Road and Baghdad Road, and a number of these lines cross the Karama Bridge. As for the second part that starts from the internal transport garage towards the ferric bridge to cross the other side of the city .See Figure (2).

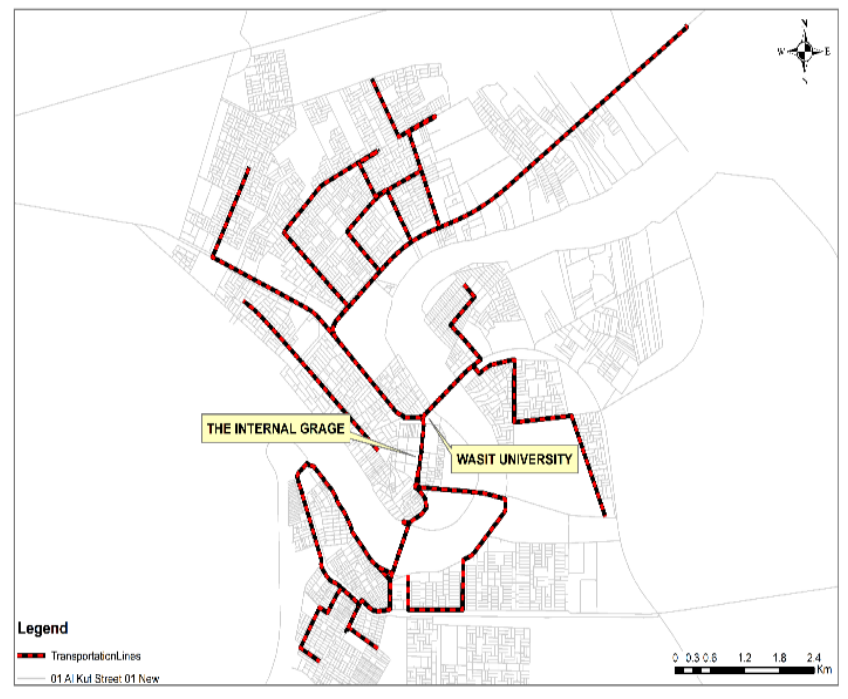

Figure 2. Public bus routes in al kut city

\section{Research Methodology}

The study of the characteristics of public bus routes in the city of Kut was based on collecting the necessary field data and calculating the number of current passengers for each route based on two survey methods:

\subsection{Ride Check Survey}

The ride check survey technique was used, and it is one of the techniques used to know the number of passengers on board the bus by calculating the number of passengers boarding and alighting for each stop and along the route, as this survey 
provides an actual service path, demand, number of stops.[11]. The survey and data collection was conducted during the trip of the public transport vehicle on each route, and to obtain more accurate data, another observer was called in, and sitting at the end of the car to control a clear view, of the boarding and alighting of the passengers at each stop, and the reconnaissance was conducted to survey the ride check for one working day at peak hour from 7-8 Morning and on typical days for each route.

\subsection{Point Check Survey}

It is a technique used to determine the passenger load of all vehicles passing at a specific point along the transit route. This technology is effectively used in developing service schedules[11]. The survey was conducted by standing at the maximum loading point identified by recording the boarding and alighting data collected from the ride check survey and along each route not shared with other transmission routes.

\section{Data Analysis}

Once the above surveys were completed, the following details were obtained:

The purpose of the ride check analysis is to offer a comprehensive evaluation of bus transit services under actual operating conditions. By analyzing ride check data, the current level of service activity and performance is displayed. The data collected was analyzed as follows:

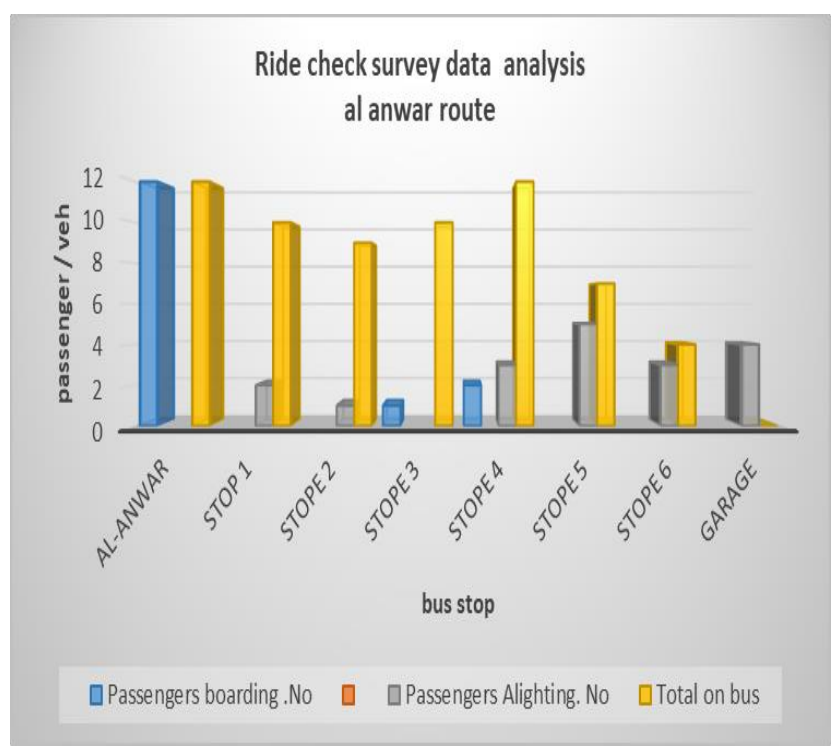

Figure 3. Boarding and alighting values and total passenger in Bus (Stops of Al Anwar route)

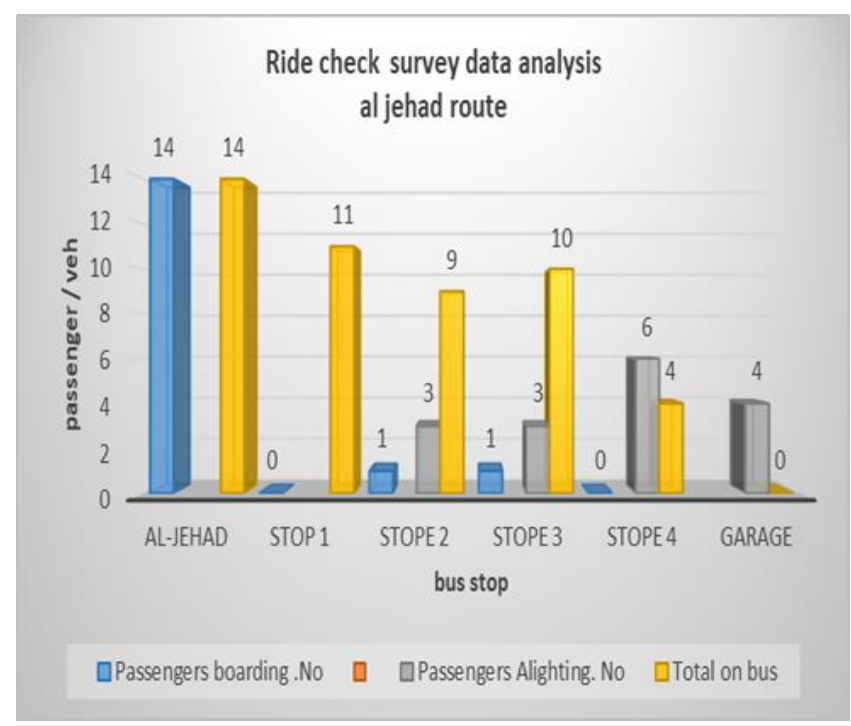

Figure 4. Boarding and alighting values and total passenger in Bus (Stops of $\mathrm{Al}$ jehad route). 


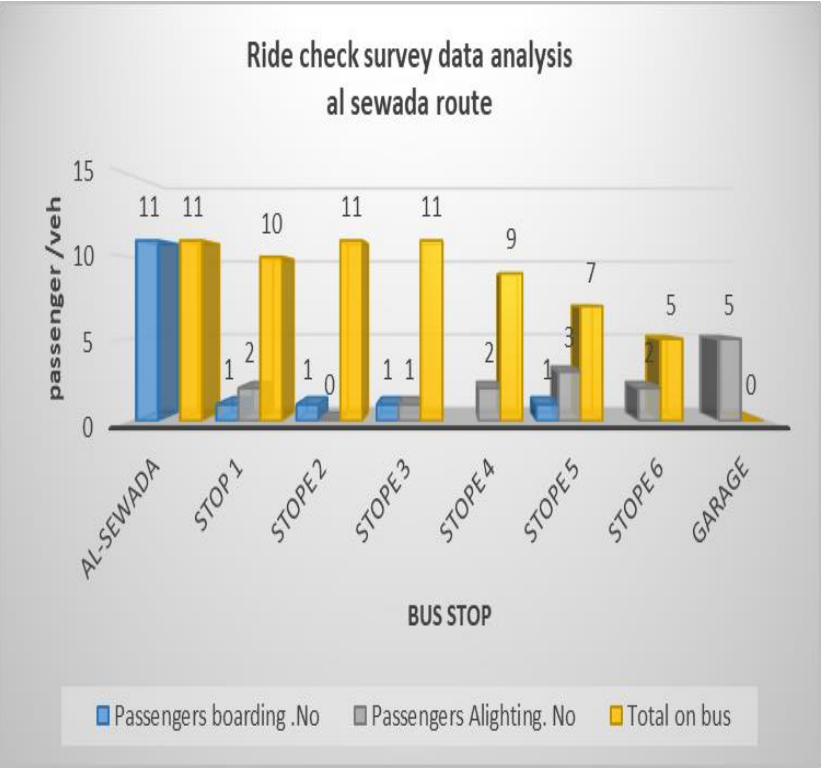

Figure 5. Boarding And Alighting Values and total passenger in bus (Stops of Al sewada Route)

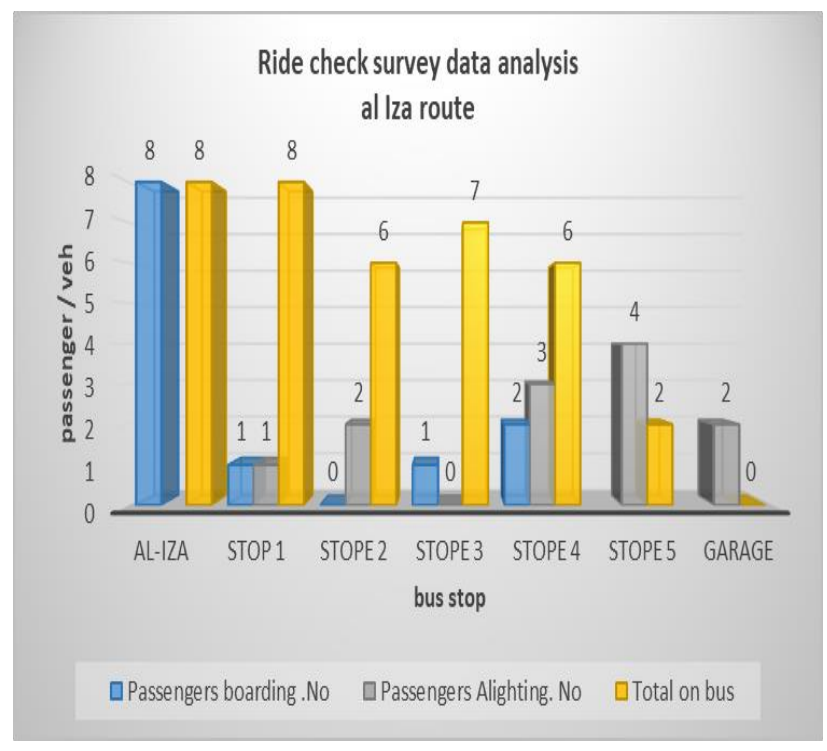

Figure 6. Boarding and alighting values and total passenger in bus (Stops of Al Iza route)

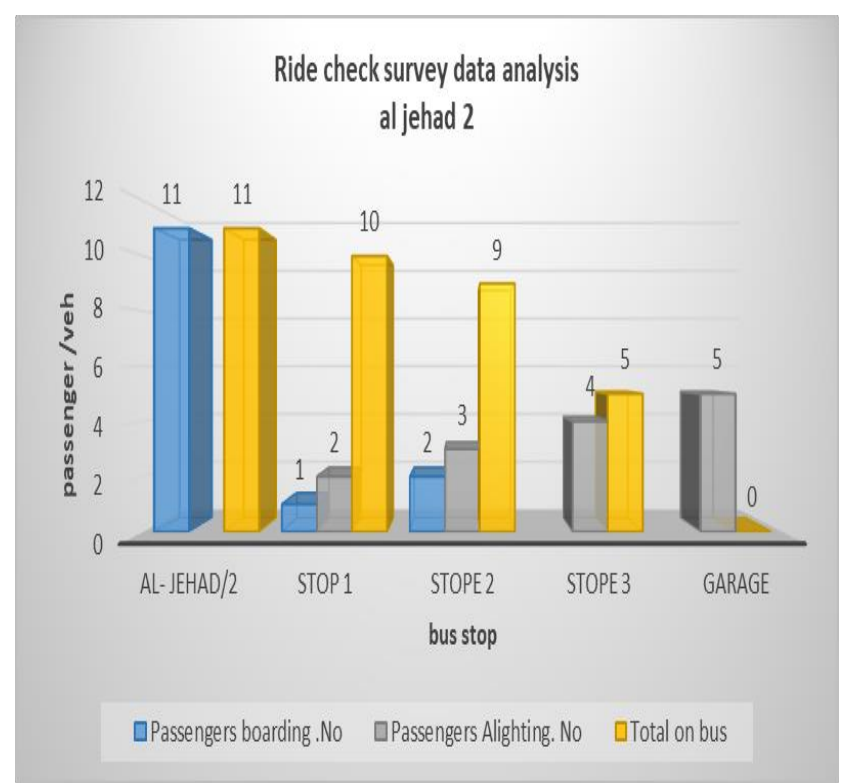

Figure 7. Boarding and alighting values and total passenger in bus (Stops of Aljehad 2 route)

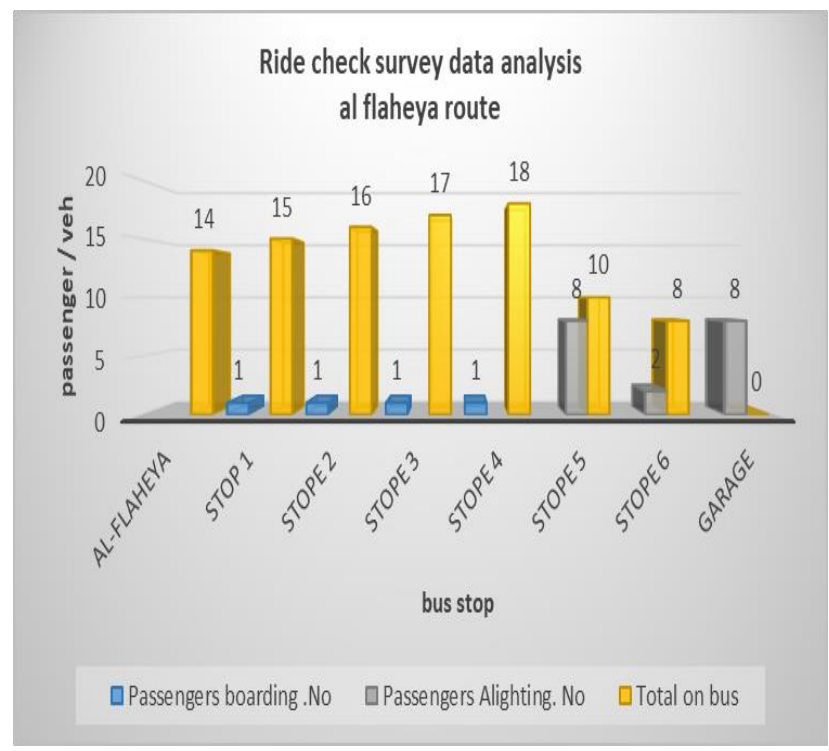

Figure 8. Boarding and alighting values and total passenger in bus (Stops of Al Flaheya route) 


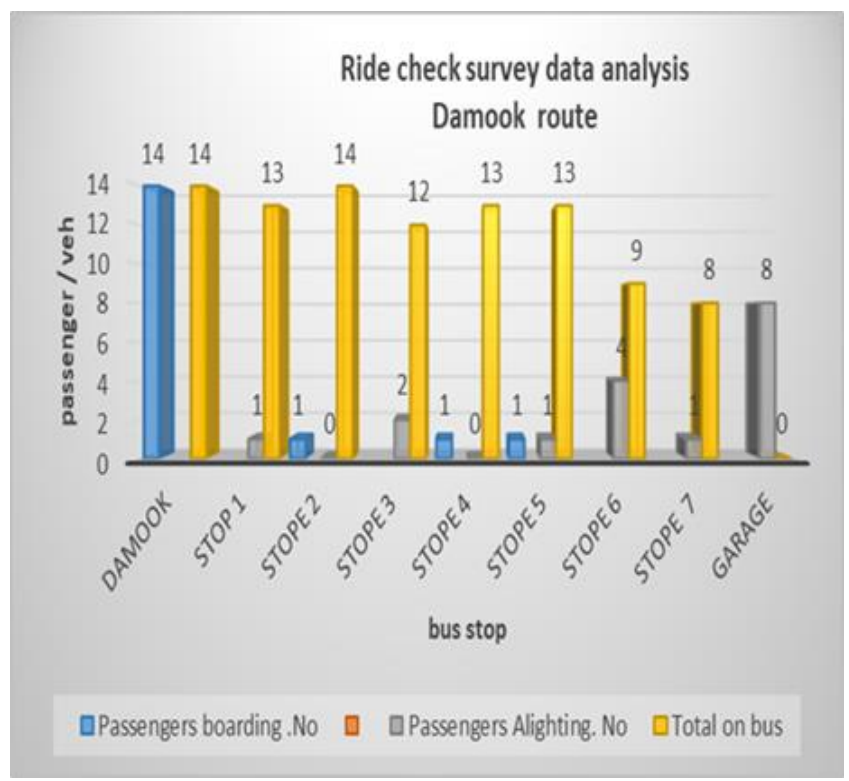

Figure 9. Boarding and alighting values and total passenger in bus (Stops of al damook route)

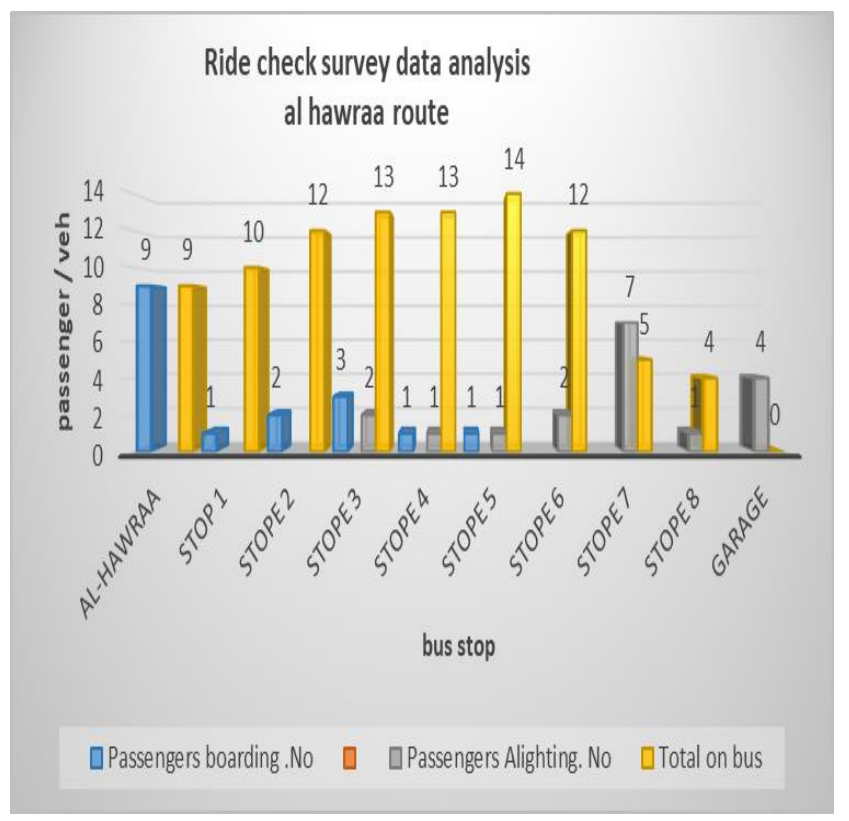

Figure 10. Boarding and alighting values and total passenger in bus (Stops of al hawraa route)

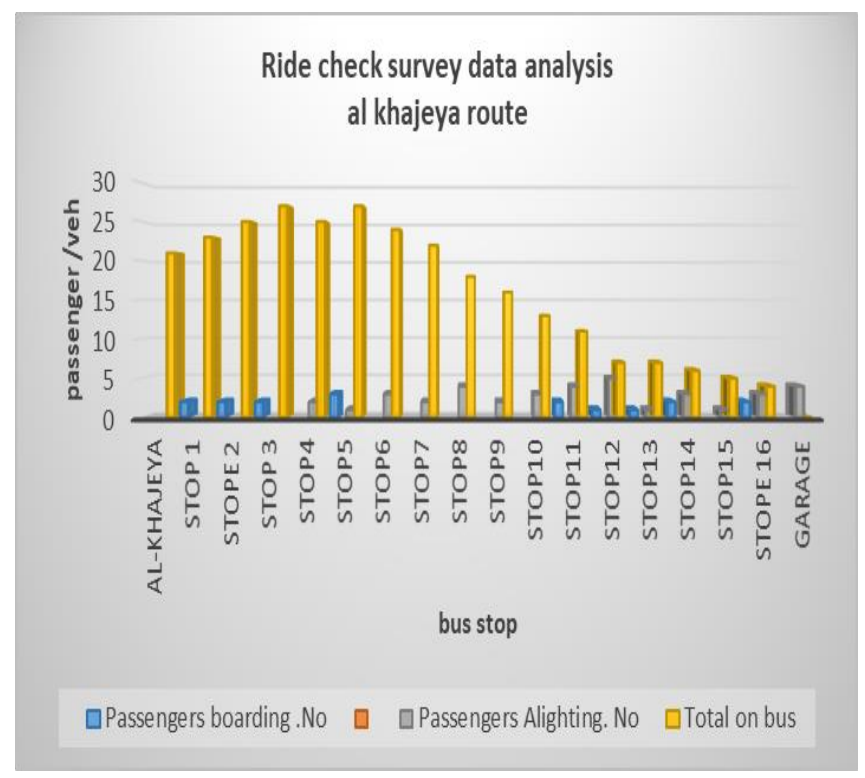

Figure 11. Boarding and alighting values and total passenger in bus (Stops of al khajeya route)

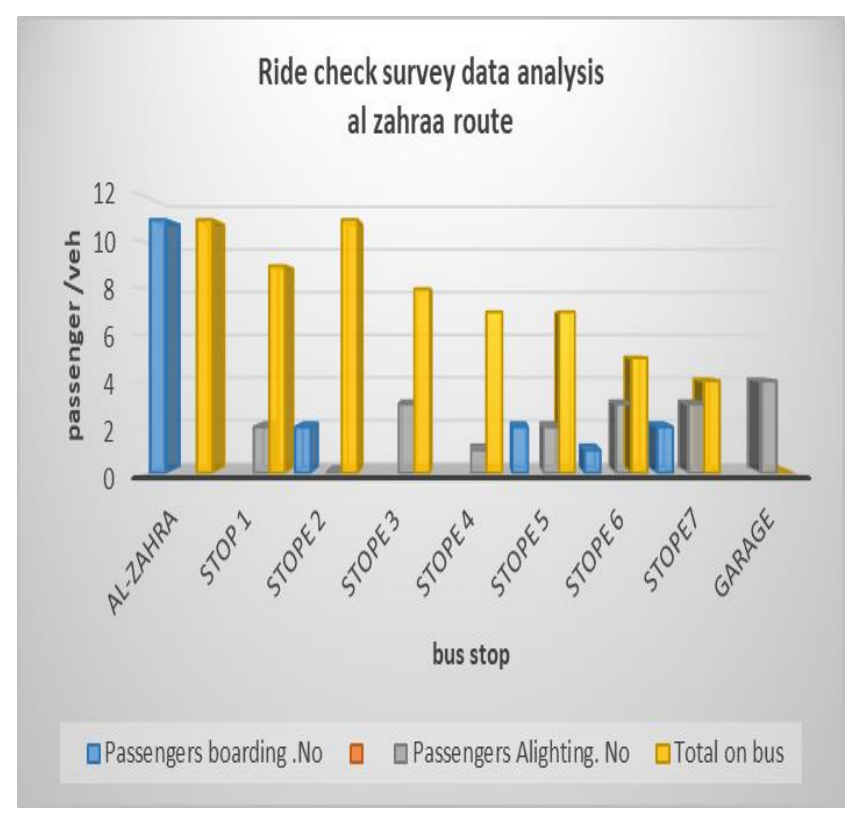

Figure 12. Boarding and alighting values and total passenger in bus (Stops of al zahraa route) 


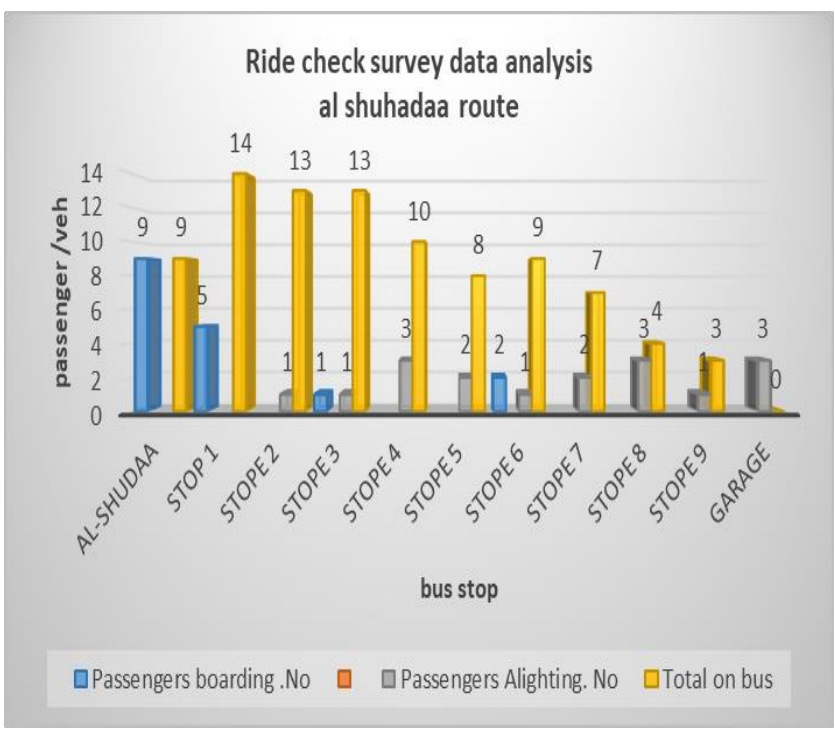

Figure 13. Boarding and alighting values and total passenger in bus (Stops of al shuhadaa route)

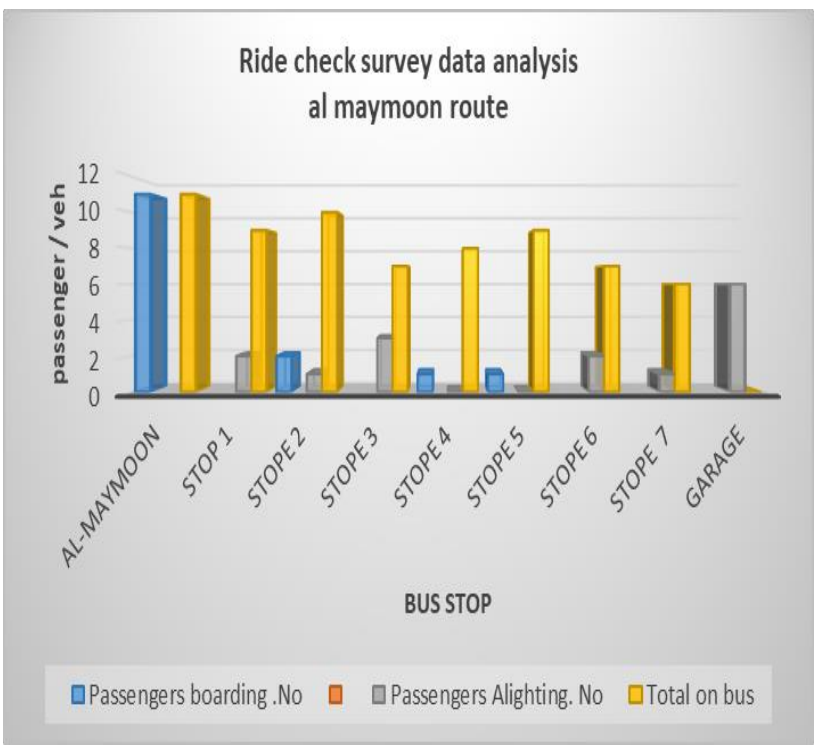

Figure 14. Boarding and alighting values and total passenger in bus (Stops of al maymoon route).

- Passenger demand was estimated through the point check survey that has been made as shown in table (1) below. The survey is consisting of account the number of bus that cross the most activity stop during peak hour.The figures (15\&16) shows number of frequency of buses during peak hour and Route load profile analysis.
Table1. Passenger demand.

$\begin{array}{cc}\text { Route Name } & \text { Demand (Pass/hr.) } \\ \text { Al Anwar } & 2560 \\ \text { Al Falaheya } & 588 \\ \text { Al Hawraa } & 2392 \\ \text { Al Iza } & 1052 \\ \text { Aljehad1 } & 624 \\ \text { Aljehad 2 } & 560 \\ \text { Al Khajeya } & 2810 \\ \text { Al Sewada } & 2880 \\ \text { Al Shuhadaa } & 1530 \\ \text { Al Zahraa } & 930 \\ \text { Al Maymoon } & 1809 \\ \text { Damook } & 1248\end{array}$

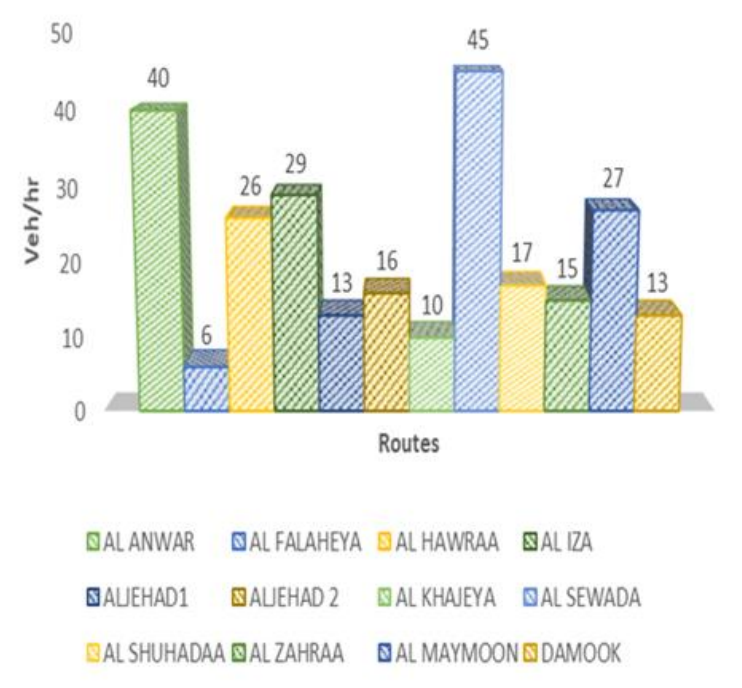

Figure 15. Frequency of buses during Peak Hour in each route

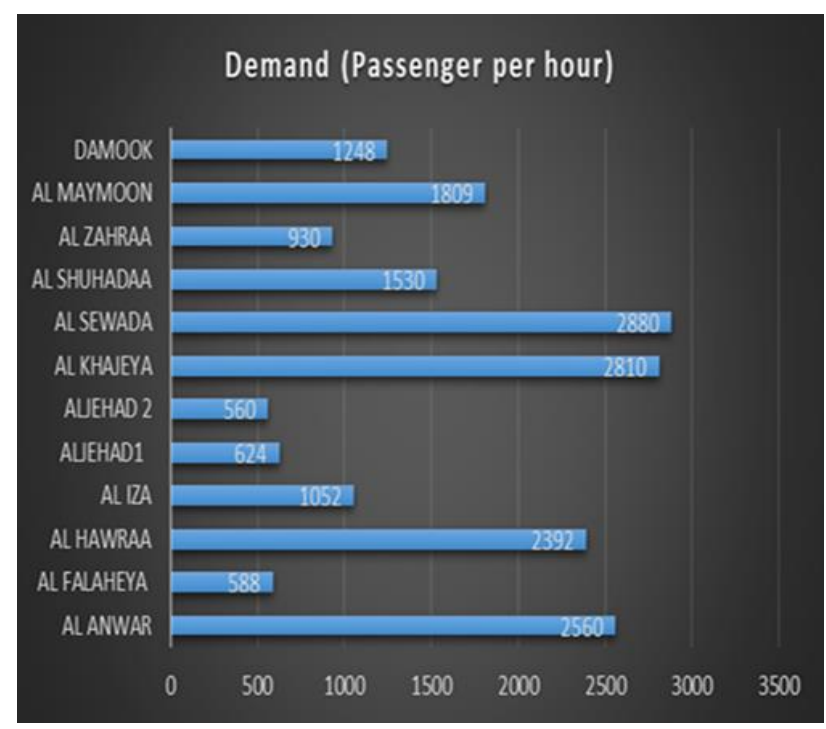

Figure 16. Route load profile analysis. 


\section{Resulte and Disscution}

- Table (2) below indicate a summary of data analysis for bus public routes in Al Kut City.

Table 2. Summary of route data analysis.

\begin{tabular}{|c|c|c|c|c|c|}
\hline $\begin{array}{l}\text { Route } \\
\text { Name }\end{array}$ & 突总 & 色苞 & 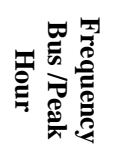 & 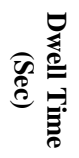 & 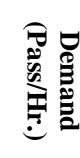 \\
\hline Al Anwar & 3.46 & 17 & 40 & 16 & 2560 \\
\hline $\mathrm{Al}$ & 6.56 & 15 & 6 & 16 & 588 \\
\hline Falaheya & & & & & \\
\hline $\begin{array}{c}\text { Al } \\
\text { Hawraa }\end{array}$ & 5.39 & 14 & 26 & 15 & 2392 \\
\hline Al Iza & 7.59 & 16 & 29 & 18 & 1052 \\
\hline Aljehad1 & 5.23 & 13 & 13 & 22 & 624 \\
\hline Aljehad 2 & 4 & 15 & 16 & 25 & 560 \\
\hline $\begin{array}{c}\mathrm{Al} \\
\text { Khajeya }\end{array}$ & 7.51 & 26 & 10 & 20 & 2810 \\
\hline $\begin{array}{c}\text { Al } \\
\text { Sewada }\end{array}$ & 10.6 & 26 & 45 & 18 & 2880 \\
\hline $\begin{array}{c}\text { Al } \\
\text { Shuhadaa }\end{array}$ & 8 & 15 & 17 & 19 & 1530 \\
\hline Al Zahraa & 4.86 & 14 & 15 & 22 & 930 \\
\hline $\begin{array}{c}\mathrm{Al} \\
\text { Maymoon }\end{array}$ & 8.255 & 19 & 27 & 13 & 1809 \\
\hline Damook & 6.61 & 14 & 13 & 13 & 1248 \\
\hline
\end{tabular}

- Through Table No. (1) the results were obtained for the characteristics that have been studied and for each route, which are the travel time in minutes, distance traveled in kilometres, dwell time in second, bus frequency during peack hour and value of passenger demand on each route.

\section{Conclusions}

- The results of the analysis in this studyshowed that the paths (Al-Sawadah, AlKhajia, Al-Anwar, Al-Hawra) have the greatest demand for travel with a value of (2880, 2810, 2560, 2392) passenger/hour respectively. Also the boarding and alighting of passengers is not high in most of the roads and that some roads are of low load.

- The bus service is ineffective at the level required for transportation service, this requires more studies to improve the performance of the transport process in the city and achieve better service, and then encourage citizens to use public transport.

- Ridership analysis provides an important role in representing transit services and achieves financial profit for transit agencies. The data of boarding and alighting for passengers can provide useful information for planners to define the bus demand for each public route. and displays the current level of service activity and performance, and through the available data, an easy way to assess the demand for public transport service is determined.

\section{Acknowledgements}

The authors are grateful to the Mustansiriyah University, College of Engineering, Highway, and Transportation Department for their support.

\section{Conflict of interest}

The authors confirm that the publication of this article causes no conflict of interest.

\section{References}

1. Yang, X., Lu, S., Zhao, W., and Zhao, Z. (2019). "Exploring the characteristics of an intra-urban bus service network: a case study of shenzhen, China", ISPRS International Journal of Geo-Information, 8(11), p. 486.

2. Fielding, G. J., Babitsky, T. T. and Brenner, M. E. (1985). "Performance evaluation for bus transit", Transportation Research Part A: General, 19(1), pp: 73-82.

3. Anderson, S. C. and Fielding, G. J. (1982). "Comparative analysis of transit performance".

4. Benn, H. P. (1995). "Bus route evaluation standards".

5. Garcia Sanchez, I. M. (2009). "Technical and scale efficiency in Spanish urban transport: estimating with data envelopment analysis", Advances in operations research .

6. Lao, Y. and Liu, L. (2009). "Performance evaluation of bus lines with data 
envelopment analysis and geographic information systems", Computers, environment and urban systems, 33(4), pp: 247-255.

7. Yetiskul, E. and Senbil, M. (2012). "Public bus transit travel-time variability in Ankara (Turkey)", Transport Policy, (23), pp: 5059.

8. Beirão, G. and Cabral, J. A. S. (2007). "Understanding attitudes towards public transport and private car: A qualitative study", Transport policy,14(6), pp: 478489.

9. Qasim, Z., Ziboon, A. R., \& Falih, K. (2018)."TransCad analysis and GIS techniques to evaluate transportation network in Nasiriyah city". In MATEC Web of Conferences,Volume 162, p. 03029. EDP Sciences.

10. Riyadh, M.(2015) "Evaluation and Enhancement of Road Network Performance at Al-Kut City Using Geomatics" Master Thesis, University of Twente, Technology.

11. Asmael, N., and Waheed, M. (2018). "Demand estimation of bus as a public transport based on gravity model". In MATEC Web of Conferences, Volume 162, p. 01038. EDP Sciences. 